\title{
WHAT'S IN A NAME? ON AFFECT, VALUE AND THE BIO-ECONOMY
}

\section{Introduction}

In a much-quoted passage of The History of Sexuality, Foucault (1991) wrote that "for millennia, man remained what he was for Aristotle: a living animal with the additional capacity for a political existence; modern man is an animal whose politics places his existence as a living being in question" (p. 143). In other words, the form of life that human and non-human animals have long shared now defines political existence; see also (Lemke, 2011). The implications of this "bio-political" mode of existence are so far-reaching that they are widely regarded as signalling the emergence of an equally distinctive economic formation, the "bio-economy"; see (Rajan, 2006), (Rose, 2007) and (Cooper, 2008). Indeed, the European Commission (2014) enabled the present discussion as part of its wider programme to understand and foster the development of European investment in this economic formation. Yet, as Birch and Tyfield (2013) observe, there is scope to doubt that the organic origins of the materials traded alters the nature of the exchanges involved. The claim to the distinctiveness of the bio-economy, they argue, fetishizes these organic materials and so deflects attention from the true source of value, namely labour. One need not agree entirely with this argument, but the relationship between the terms that the bio-economy conjoins is undoubtedly complex and has become the object of much critical reflection. Tellingly, if the phrase "species existence" aptly summarises Foucault's understanding of modern existence, it is also critical to Marx's analysis of labour and the production of value, and it is no surprise therefore that such critical reflection should sometime take "species of capital" as its principal term of reference (Helmreich, 2008). This paper examines some of the issues at stake in this bio-economic conjunction. It does so by attending to the role that the preservation of three breeds of sheep plays in the economic regeneration of once 
productive agricultural communities; see also (Evans \& Yarwood, 2000) and (Berry \& Palladino, in press). On the one hand, the paper proposes that, despite these sheep's pivotal role in the production of value, there is little about the enterprises to warrant the notion of a distinctive economic formation. On the other hand, the practice of naming the sheep prompts an exploration of the extent to which the affective relations associated with the investment in these breeds exemplify the transition to a veritably bio-economic formation, in which the organic origins of the materials traded are as significant as has been proposed; see also (Dussauge, et al., 2015). ${ }^{1}$ While these considerations extend Haraway's (2008) analysis of "lively capital" (p. 45), they also endeavour to move beyond any opposition of materiality and discursive representation, including its hybrid variants. In so doing, the paper strives to bridge the gap between Haraway and Deleuzian understanding of species existence (Beaulieu, 2011). The bridge thus forged may also serve to overcome tensions between Birch and Tyfield's argument and the "autonomist" perspectives on which they draw to question the notion that the contemporary convergence of economic exchange and species existence signals the emergence of a novel and distinctive organisational form. Finally, the considerations about affect and value that are involved in these contributions respond to the growing calls to examine more systematically the place of non-human animals in the understanding that "modern man is an animal whose politics places his existence as a living being in question”; see (Wadiwel, 2015); also (Chrulew \& Wadiwel, 2016).

The proposed examination of the relationship between affect, value and the bio-economy is articulated in three parts. The first offers an introduction to on-going discussions about the nature of the contemporary convergence of economic exchange and species existence. If, as Franklin (2007) argues, Dolly, the sheep and first cloned, transgenic mammal ever produced, who is today embalmed and on display in the National Museum of Scotland, serves as an 
icon for such convergence and its disruptive implications, the second part of the paper turns to three very different, but equally iconic sheep, namely the Xisqueta, the Sambucana and the Herdwick. ${ }^{2}$ The Xisqueta, native to the Catalan Pyrenees, serves as an icon for the insurgent and arguably counter-hegemonic endeavour to revive the peasant mode of production by developing a school for shepherds, as well as all the social and economic structures necessary to secure the success of this endeavour. The complexity of this endeavour is explored by juxtaposing it against the enterprises that have evolved around the Sambucana and the Herdwick, breeds peculiar to the Maritime Alps and the Lake District. In so doing, this part of the paper places the activities around the Xisqueta in the context of new forms of consumption and commoditisation, so serving to call into question the notion that the contemporary convergence of economic exchange and species existence amounts to the emergence of a distinctively bio-economic formation. On the other hand, the third and final part of the paper suggests that, if the activities around the Xisqueta are at all counterhegemonic, this owes to the distinctive role of the sheep involved as singular, yet plural, sites of disruption and reconfiguration. Icons, positioned as they are between representation and the singularity of the thing in itself, have long proven disruptive objects, and the present situation seems no different (Belting, 1994); see also (Buller, 2004).

With respect to method, the argument's articulation will rest on the combination of interviews, ethnographic observations and a reading of the existing historiographical record, and the approach taken is genealogical (Foucault, 1977). In other words, the economic operations involving the Xisqueta, around which the argument revolves, are to be understood as posing questions about local forms of life and their future, which the actors involved have addressed by drawing on disparate practices of commemoration and commoditisation. Developments around the Sambucana and the Herdwick serve to illustrate what these 
otherwise generic practices would appear to entail. From this point of view, these iconic breeds take on the attributes of ideal types, but the approach also is genealogical in the sense that it draws attention to the contingency, if not the experimental nature, of the integrations sought and is interested in the effects of the alignments achieved. ${ }^{3}$ In this last sense, the analysis offered converges upon Campbell, Le Heron, Lewis, and Carolan's (2016) combination of post-structural political economy, more-than-human geographies and performative theory to understand the construction of value within contemporary bioeconomies. In sum, although the approach taken will sometimes seem to involve contrasts between overly abstracted organisational forms, the aim is to glimpse the potential for disruption in each and every "form-of-life" (Agamben, 1996); see also (Law \& Mol, 2008). ${ }^{4}$

\section{Mapping the bio-economy}

Over the past two decades and more, the number of critical perspectives on the bio-economy has grown exponentially, reflecting the growth and diversification of investment in the generative power of organic materials. Helmreich (2008) has sought to organise these critical perspectives by distinguishing between discursive and materialist approaches. ${ }^{5}$ While this distinction calls for some explanation, it should also be noted that the literature Helmreich reviews tends to privilege techno-scientific sites, to the detriment of the organism and its distinctive organisation of generative power. This is increasingly at odds with the growing importance that is attached to non-human animals to understand contemporary bio-political governance, including its bio-economic forms (Asdal, et al., 2017); see also (Twine, 2010) and (Chrulew \& Wadiwel, 2016). Consequently, it is helpful to begin the work of explanation by contrasting two accounts that not only illustrate the differences and similarities between discursive and materialist approaches, but also attend to the relationship between capitalist economic formations and the lives of non-human animals. 
As the organism recedes from sight and discussions of the bio-economy focus ever more on the circulation of the organism's component parts, Shukin (2009) seeks to develop a vocabulary that will enable greater insight into the role of non-human animals in mediating the relationship between the discursive and material ordering of contemporary bio-political existence. Beginning with the manner in which the anatomical diagram of a beaver holds together the operations of capital and identity of the Canadian nation-state, Shukin offers "rendering" as an especially useful figure of speech. Not only does it help to map the many ways in which the contemporary convergence of economic exchange and species existence complicates the relationship between capital and the commodities traded, but it also discloses the intrinsic violence of the relationship. This figure discloses how the discursive equations enabling the exchange of one thing for another, on which rests the "lively" capacity of capital to create value, are inseparable from the material disarticulation of non-human bodies. Of course, this situation is no coincidence since it is linked historically to earlier, formative incarnations of the relationship between species existence, economic exchange and the growth of capitalism; see also (Cronon, 1992, pp. 207-259). Shukin's analysis of the looping movement between these discursive configurations and material articulations culminates in the conclusion that "the sinister prospect accruing to the double logic that rendering describes is that of capitalism's potential interminability, a perpetual existence supported by the ability to materially and semiotically recycle its conditions of possibility ad nauseam” (p. 231). In other words, the reordering of the material world can interrupt, but not undo, the discursive configuration of this same world. Arguably, however, this disheartening conclusion is an effect of the exclusive focus on representation and the simultaneous rejection of the ontological assumptions sustaining the principal intellectual resources that Shukin mobilises to interrogate these representations, chiefly Derrida and Deleuze. ${ }^{6}$ As a result, what Shukin's analysis offers is the details of something like a Foucauldian apparatus, in which disparate 
objects and practices are tied into seamless webs of signification (Foucault, 1980); see also (Legg, 2011). This is not dissimilar to the analyses that Helmreich (2008) cites as exemplifying a discursive approach to the analysis of the bio-economy, which, as a consequence of its methodological predilections, is unable to confer any transformative agency upon the bodies that supposedly distinguish this from other economic formations.

Franklin (2007), on the other hand, illustrates a materialist perspective on the bio-economy, which, as Helmreich (2008) puts it, holds out the hope of undoing "the capitalocentrism of so much writing on biocapitalism" (p. 474). Thus, Franklin turns to the diverse forms of life that have sustained the emergence of Dolly, the cloned, transgenic sheep capable of producing the molecular precursors of potentially valuable therapeutics. Sheep and the evolution of modern economic formations have long been intertwined, but, Franklin argues, the emergence of Dolly signals the importance of reproduction over and above production to the evolution of a distinctively bio-economic formation. More specifically, the experimental farm from which Dolly emerged was no agricultural site dedicated to the transformation of non-human species into self-reproducing sources of agricultural commodities, but a site of molecular reconfiguration, dependent upon, but unconstrained by attachment to any particular organism. Such reconfiguration results in the production of compounds capable of circulating freely and today feeding a highly lucrative, speculative market in bio-synthetic futures. In other words, wealth comes to depend upon the isolation and mobilisation of the organism's reproductive capacities, and does so in a manner very similar to that which Marx once attributed to soil, though, as Franklin also observes, Marx appears to have been much confused about the relationship between production, reproduction and the origin of capital (pp. 106-7). To put it simply, Franklin maintains that capital without the specificities of body, place and practice is nothing. Yet, Dolly's naming would also seem to have been important to assuaging the many 
fears that the transgressive processes involved in Dolly's production also engendered. By transforming clone 6LL3 into Dolly, this otherwise troubling organic bio-reactor was reconnected reassuringly with the most traditional husbanding practice, the naming of the animals; see also (Derrida, 2008). Dolly can then be regarded as an iconic figure for the transformative potential of contemporary economic investment in the disconnection of reproductive capacities from the specificities of both the organism and the organism's historical sites of reproduction. As such, this is a figure not very different to the beaver with which opens Shukin's analysis of the relationship between economic exchange and contemporary bio-political existence.

In sum, although discursive and materialist perspectives on the relationship between species existence and economic exchange differ in their method, they not only seem to agree that there is something distinctive about the bio-economy, but they are also equally unable to specify exactly what this might be. This situation has prompted Birch and Tyfield (2013) to argue that much of the literature on the bio-economy fetishizes the objects that supposedly differentiate this from other forms of economic exchange. In other words, insofar as this literature insists on the distinctiveness of the bio-economy, it cannot but regard economic value as stemming from features of the materials exchanged, in themselves, rather than from the labour involved in their production, so mistaking that which is constructed and secondary as given and primary. While Birch and Tyfield then proceed to argue that these materials should be regarded as assets rather than commodities, and thus as objects of rent, for the purposes of this paper the more important issue is the relationship between discursive and materialist perspectives. Not only does the very notion of the fetish rests on a troublesome opposition of the two perspectives, but its mobilisation may underestimate the importance of the contemporary pluralisation of modes of understanding the creation of value beyond the 
constraints imposed by the labour theory of value, including Haraway's (2008) evocation of a lively form of capital, dependent on the "encounter[s]" between different species, human and non-human (p. 46); see also (Grossberg, et al., 2014) and (Barua, 2016).

The discussion will therefore turn to the mobilisation of sheep in the Catalan Pyrenees, the Maritime Alps and the Lake District, to examine the complex ways in which production of economic value comes to be indebted to the lively nature of these sheep. The claim resulting from this examination is that the mutual dependence of humans, non-human animals and place that is observed in the Catalan Pyrenees is best understood as an affective relationship, and not just as the site of encounter, but, to draw on Deleuzian terminology, as a site of “intensive” flow (Deleuze, 2004); see also (Dunham, et al., 2014, pp. 287-90) and (Buchanan, 2008, pp. 161-84). Strikingly, apart from occasional references, Deleuze and Deleuzian thought are largely absent from the literature on the bio-economy; cf. (Rabinow, 1996). This is possibly because Deleuzian thought is often regarded as uncritical, if not complicit, with the capitalist economic order. The more immediately important source of ambivalence may be, however, its supposed fetishization of vital capacities and simultaneous disregard for the lives of non-human animals, despite Deleuze's famed celebration of "becoming-animal" as a form of emancipatory politics; see (Haraway, 2008). ${ }^{7}$ The criticism is not without merit, but the wider significance of the proposed turn to Deleuze and Deleuzian thought is that it may help to overcome the opposition between discursive and materialist perspectives, which arguably persists in the understanding of encounter value, to detriment of the very truth which this concept seeks to capture. In so doing, the argument also contributes to opening up ongoing discussions of the relationship between economy and species existence to a wider range of understandings of both terms; see (Grossberg, et al., 2014) and (Wadiwel, 2016). 


\section{Learning to be a shepherd}

In 2009, the Associació Rurbans (Rurbans), a voluntary organisation dedicated to the economic renewal of communities in the Catalan Pyrenees, together with Obrador Xisqueta, a newly developed association of sheep breeders, established the Escola de Pastors de Catalunya (EPC) (Associació Rurbans, n.d.). Since then, the EPC has offered young people from across Spain, from both rural and urban backgrounds, an opportunity to learn the business of shepherding and secure employment not just as shepherds, but also in a whole range of ancillary occupations. Insofar as this enterprise can be said to have resulted in a more sustainable form of life for an otherwise struggling region, this rests on an explicit aspiration to reorder the movement of capital.

As Ploeg (2008) observes, the difficulties confronting contemporary agricultural producers worldwide have led many to either abandon production or minimize their engagement with the market. The latter response effectively returns the producers to the status of peasants. Some have actively embraced this process of global "repeasantization", aiming to forge a new "bio-civilisation" (Goodman \& Salleh, 2013); see also (Porcher, 2017). Following suit, Rurbans seeks to enable a return to the peasant mode of production (Monllor, 2013a); see also (Monllor, 2013b). Focusing its activities around a local breed of sheep, the Xisqueta, Rurbans seeks to rebalance the contemporary, dominant association of ovine production with meat consumption, by encouraging the diversification of production, including the return to the very production of wool and woollen textiles whose historical development progressively drove local shepherding to the margins of the global economy (Fontana, 2004); see also (Phillips \& Phillips, 1997) and (Echegaray, 2012). Some of this is managed through Xisqueta $\odot$, the trading company which Rurbans has set up to retail its members' output, and the ultimate aim of this and other, related enterprises is to employ the profits generated to 
renew otherwise dying local communities; see also (Mármol \& Vaccaro, 2015). As Ploeg might put it, the rate of extraction in these new peasant enterprises may be lower, but the proposed redistribution of surplus value secures a more sustainable relationship between economy and society.

Admittedly, policies privileging large landowners and corporate forms of agricultural production are a major source of difficulty for Rurbans. As interviews with graduates of the EPC document, limited access to land is a major constraint upon the successful integration of new agricultural producers and upon the consequent renewal of local communities (Ahumada, 2013). Time will tell if anything will come of enterprises such as the EPC. In the meantime, however, a still experimental blending of wool from the Xisqueta with wool of the Merina Negra, which is produced by the members of Laneras, a cooperative located in distant Extremadura, promises to multiply the political leverage and transformative ambitions of Big Brother Bio Farming, an umbrella for social enterprises such as Rurbans and Laneras (interview with community organiser, 14 August 2015); see also (ACTYVA, 2013). Furthermore, the wool and woollen garments that Xisqueta $@$ sells on metropolitan markets connect this network not just with a new generation of ethical consumers, but also with social enterprises across Spain, France, and, increasingly, the entire European Union (Accesstoland, n.d.); see also (Marsden \& Murdoch, 2006) and (Lang, 2010).

In sum, Rurbans mobilises the Xisqueta to weld together the renewal of local, rural communities and global concern about the development of more sustainable modes of agricultural production. The bio-economic and counter-hegemonic nature of this enterprise is understood best by examining first how the relationships forged with non-human animals might also be regarded as a wholly conventional economic enterprise, in the knowledge that subversion of existing relationships is the distinctive feature of all counter-hegemonic 
practice (Gramsci, 2007). The next part of the paper will therefore focus on activities in the Maritime Alps, aiming to explore how the commoditisation of memory transforms lives lived in the company of sheep into the production of a novel breed, the Sambucana. It will then attend to the Herdwick, aiming to explore how successful commoditisation of such breeds breaks the link with the animal of flesh and bone, transforming it into a branding device that is wholly disconnected from both the animal and the place in which it originates, in this case the Lake District.

\section{Genealogy}

\section{a. The construction of a lost tradition}

The Sambucana is a product of the crisis confronting the modern organization of food production, particularly as it has unfolded in Italy.

As Ploeg (2008) observes, Italy is one of the global leaders in the contemporary capitalisation and financialisation of food production. So, for example, an extraordinary combination of financial engineering and the reconfiguration of ubiquitous and seemingly uncomplicated products such as fresh milk into vehicles for the aggregation of dairy production and processing on a global scale transformed Parmalat into one of the largest food conglomerates in the world. That the speculative bubble that was Parmalat eventually burst is immaterial because a number of even more invisible conglomerates have acquired its assets. The emergence of a now global Slow Food movement is inseparable from public discontent not just with the social and economic destruction wrought by such conglomerates, but also, and perhaps more importantly, from increasing concern about the quality of the food these conglomerates place on the global kitchen table (Craig \& Parkins, 2006); see also (Grasseni, 2013). This context is important to understanding the emergence of the Consorzio 
l'Escaroun, a producers' cooperative dedicated to the promotion of the Sambucana and the consumption of Agnello Sambucano, the Sambucana made into lamb and mutton (Brignone \& Martini, 2012).

The Sambucana first came to public prominence sometime around 1985, when it was introduced as a novel display at the annual All Saints fair in Vinadio, in the higher reaches of the Valle Stura, in the Maritime Alps. Aiming to enhance the attractiveness of an otherwise inhospitable valley, the Sambucana featured both as live sheep to be judged for trueness to traditional ovine standards and as hogget for tourists' gastronomic delectation. This endeavour was then consolidated in 1988, by constituting the Consorzio l'Escaroun. Significantly, while the investment of the European Union in the preservation of animal genetic resources may have been important to the enterprise, the latter also was an early contributor to the development of the Slow Food movement, the Sambucana having featured in the first issue of Slowfood, one of the movement's earliest publications (Luparia, 2000); see also (Lebaudy, 2011). These different investments were integrated by drawing on the recording practices that were developed in the course of re-establishing the Sambucana to enable the traceability of the animal, from whole sheep to meat on the table, so facilitating consumers' rethinking of their relationship to the food eaten and its provenance. Since 2012, the identity of each sheep brought to market is guaranteed by an official identity card, which every butcher and restaurant retailing Agnello Sambucano is required to display. ${ }^{8}$

As the Pecora Nera, the Black Sheep, the Sambucana lends its name and its iconographic rendition to a variety of local products and amenities, but meat is the mainstay. This said, one of chief challenges confronting the Consorzio l'Escaroun is how to promote local and regional consumption of lamb and mutton, because, historically, it is very limited (Kanerva, 2013); on the ecology of meat consumption, see (Emel \& Neo, 2015). Thus, when the local 
authorities supported the creation of the Consorzio l'Escaroun, they also lent their support to the establishment of an ecomuseum dedicated to the commemoration of shepherding (Biffi, 2014). The ecomuseum's photographic exhibitions provide the required, distinctive backstory by linking the consumption of ovine meat to a slower, lost world of transhumant shepherds, a link that visitors are also able to enact by dining in the restaurant associated with the ecomuseum. Strikingly, however, sheep are largely absent from renowned photographic records of life in the area; see (Audisio \& Cordero, 1996). The reason for such dissonance is that shepherds captured in the photographs on display in the ecomuseum did not obtain their livelihood from any local sheep, but by moving commercial flocks of Merino from the western reaches of Provence, to the Maritime Alps and back, flocks bred for the purposes of the wool, rather than meat trade. Ironically, upon their return to the mountains, these shepherds were sometimes given a lamb, partly as payment and partly as a gift, a lamb that they then crossed with their own small flocks of sheep. The results of such crossing are now to be undone, to recover the real and authentic past of the Valle Stura (Lebaudy, 2011). As such, the Sambucana is best regarded as an "invented tradition", if not a "brand", here impressed upon the very flesh of the sheep (Hobsbawm, 1983); see also (Graham, et al., 2000), (Colombino \& Giaccaria, 2015) and (Holloway, 2015). It is not clear, however, to what extent the value accrued in the process of commoditising such tradition owes to the Sambucana's lively nature, perverse as this understanding of the Sambucana's fate may seem. The eating of Agnello Sambucano is perhaps better understood as a new form of gastronomic consumption, tied to place and tradition (Goodman, 2016); see also (Evans \& Miele, 2012). Paradoxically, as Grasseni (2013) observes, the standards that organisations such as Slow Food introduce into this sector of the contemporary consumer economy result in the further erosion of the communities out of which breeds such as the Sambucana emerge. 


\section{b. From product and brand to the economy of branding}

Herdy is a highly successful commercial design company and it is named after the Herdwick, a breed of sheep that is peculiar to the Lake District (BITC, 2010) and (IPO, 2015); see also (Brown, 2009).

Herdy emerged in the wake of the destruction wrought by the epidemic of Foot and Mouth Disease that gripped the United Kingdom in 2001. As public authorities culled livestock to eradicate the outbreak, the small number and geographically circumscribed distribution of Herdwick sheep brought the breed close to extinction. The fate of the Herdwick acted as a lightning rod for increasing public unease over the killing and burning of livestock by the million; see (Franklin, 2007) and (Law \& Mol, 2008). Upon moving to the Lake District, the company's founders drew on the sheep's increased public visibility to create a new, more modern image for the Lake District, which otherwise is regarded as the repository of the most traditional understanding of the English landscape (Ritvo, 2009). Importantly, the founders also committed themselves to reinvesting a share of the profit generated by their business within the local community, through the Herdy Fund, the Herdwick Sheep Breeders Association and the latter's programme to secure the continued existence and prosperity of the Herdwick (interview with commercial director, 5 May 2016).

One of the most notable achievements of the collaboration between Herdy and the local community has been the successful application to the European Union for exclusive trading rights under its Protected Designation of Origin scheme, which, exceptionally, was extended not just to the products associated with the Herdwick, but to the Herdwick sheep itself (Mansfield, 2008); see also (Brown, 2009) and (Lang, 2010). Herdy then organised the marketing of Lakeland Herdwick, the Herdwick turned into meat. Strikingly, not all farmers 
have supported the enterprise because the benefit to the local farming community is constrained by the enforced association of sheep and place, so much so that, for example, any grazing of Herdwick sheep outside the Lake District, even on nearby uplands, disqualifies the meat obtained from the butchered sheep from sale as Herdwick lamb or mutton (interview with local farmer, 11 June 2016). Metropolitan food critics such as Rayner (2016) are equally unhappy. Rayner draws attention to the rejection of industrial modes of that is involved in the emergence of the Slow Food movement and the related demand for Lakeland Herdwick, but also bemoans how the tying of the Herdwick and the Lake District together restricts the supply and raises the price of Lakeland Herdwick, asking finally and very pointedly who really benefits from the situation, consumers or producers. Rayner's concerns are not illfounded, but the more immediately important point is that Herdy is able to distance itself from the difficulties Rayner's intervention has generated for the producers of Lakeland Herdwick. Unlike these producers, Herdy sources most of the merchandise it retails beyond the confines of animal and place, selling it across the globe and at the premium that ethical consumption is able to command. This disconnection is consummated with the opening of a Herdy retail point in the Yorkshire Dales, a region renowned for its flocks of Swaledale, rather than Herdwick.

As observed earlier, Birch and Tyfield (2013) have argued that analyses of the contemporary convergence of economy and species existence rest on the fetishization of organic forms of life. Herdy's creation of value would seem to illustrate this process. Herdy first helps primary producers to construct a distinctive identity for their livestock, by investing in genetic and agro-ecological improvement, and then, as if to illustrate Shukin's (2009) understanding of "rendering", Herdy separates the identity thus constructed from the animals themselves, transposing it onto spatially and culturally removed material objects, enabling their sale far 
and wide. As Pike (2015) observes, the construction of an effective brand involves the skilful management of both relations between brand and product, and movement between local and global scales; see also (Colombino, 2018). The effects of such operations are far from trivial since Herdy then was the obvious choice to act as lead agency in the successful bid to transform the Lake District National Park into a UNESCO World Heritage Site, its iconographic rendition of the Herdwick acting as symbol for the bid, so redoubling the value of the brand. Once again, despite the importance of animal and place, it is not clear what the creation of economic value owes to liveliness, as opposed to the dynamics of "origination".

\section{Encounters, intensities and ties that bind}

Rurbans, the enterprise built around the sheep of the Catalan Pyrenees, combines the two aspects of commoditisation that the Consorzio l'Escaroun and Herdy exemplify. The former mobilises a breeding programme to produce a commodity whose value stems primarily from connecting the act of gastronomic consumption and memories of a lost, slower world. If the endeavour is stymied by the limited opportunities afforded by the ties between animal, place and consumers, Herdy has become a highly successful enterprise by breaking free from all ties to animal and place, bar their iconic rendition. There is nothing lively, let alone counterhegemonic, about such strategies of commoditisation. At the same time, however, there is something insurgent about Rurbans and it comes to the fore in the relationship to the sheep involved. If Rurbans is able to tie the dynamics shaping the Consorzio l'Escaroun and Herdy to counter-hegemonic ends, it is because Rurbans returns to the animals themselves, to the encounter between human and non-human animals (Haraway, 2008). 
Ahumada (2013) has conducted a number of interviews with graduates of the EPC. Two of these graduates summarise the nature of shepherding as both a form of work and a relation between humans, sheep and the landscape. As they put it:

\footnotetext{
It is another life! ... It's not the eight hours of salaried work. You may have to work twelve hours, but at your own pace and as you wish. You get to know each sheep, you see how they grow and you become attached to them. It's different ...

It's a very strange kind of connection because you suddenly start to feel as if you, the sheep and the landscape are one (p. 25 and 30).
}

At the same time, the following exchange between two other graduates conveys the difficulties involved in the functional nature of this otherwise intimate relationship:

\begin{abstract}
Seeing them entering the slaughterhouse was traumatic. That was when I said 'I have had enough and want to do it my way'...

You cannot invest too much affection in animals who you will have to sell or sacrifice. Since they ultimately are commodities, all that you can offer them is the best life possible, feeding them well, being patient and not making them bear the brunt of your own limitations ...
\end{abstract}

I know all this, but when you identify one in particular and you put a name to it ... (pp. 76-8).

Strikingly, the halted, incomplete nature of the closing statement, conveyed by the conventional use of ellipsis, “i li posis un nom ...” in the Catalan original, recalls Agamben's (1999) discussion of this syntactical term. There are a number of things that can then be said about this conjunction of the act of naming and its suspension.

Firstly, Agamben draws on Deleuze's "Immanence: A life ..." (2001) to argue that the conjunction of the act of naming and its suspension is the signature of "life itself", a form of life beyond the grasp of power and knowledge. One need not embrace Agamben's vitalist assumptions about an immanent, self-moving power. ${ }^{9}$ It bears noting, however, how Derrida's (2008) reflections on Adam's naming of the animals in the Garden of Eden associate this act and the granting of human sovereignty over animal existence, but they also point to God's surrender of sovereignty over Adam. As such, Adam's naming of the animals 
is a free act. Viewed from this perspective, naming can then be regarded as an ambiguous act, pivotal to objective classification, but also individuating and so opening onto responsibility. The ellipsis signals this relationship that exceeds the capacities of language to capture its full meaning. On this understanding, it is important not to overlook how, even when destined for slaughter, each named animal has its story and how this individuating, singularising story is fundamentally important to the relationship between the like of shepherd and his or her sheep (Fontana, 2004); see also (Aime, et al., 2001) and (Despret \& Meuret, 2016). At the very least, such intimate relationship is vitally important to the investment of labour that the renewal of the peasant mode of production requires (Porcher, 2017); see also (Buller, 2013). ${ }^{10}$

Secondly, if Rurbans can be regarded as acting as a vector of global political transformation, its gains would seem to stem from the grounding of the enterprise in the specificities of the particular form of life that the conjunction of name and ellipsis signals. Thus, for example, Rurbans' organisers deploy the notion of iconic representation reflexively, rejecting any disproportionate insistence on the genetic identity of the Xisqueta (interviews with community organiser and local farmer, 15 August 2015). To Rurbans' members and the EPC's graduates, the enterprise is about the reproduction and renewal of a local and distinctive form of life, which, simultaneously, calls on them to move outside themselves, connecting with others, not just consumers, but also the non-human animals on whom the enterprise depends. This resonates with Porcher's (2017) ethnographic reflections on life and death in the modern slaughterhouse, which are equally attentive to the lives of non-human animals, to the relations between these animals and those whose task it is to butcher them, and to the consumers who would reject the forms of life dependent on the slaughterhouse. Drawing on Mauss' understanding of sociality to displace Marx's understanding of labour 
and to propose instead that the slaughtered animal should be regarded as enabling the continuation of life by donating their own, Porcher proposes that "the tie means more than the commodity ... the value of the tie is of more importance than the value of the usage and the value of the exchange" (p. 104). Put differently, Porcher proposes that the affective ties between human and non-human animal that are built up over the course of working lives lived together, from birth to death, are a source of valuation that exceeds the calculations on which use and exchange value are supposedly predicated. Returning to Rurbans, it is openness to these ties, to the obligations which they and their interruption entail, that makes each and every member of the collective part of a lively and insurgent "form-of-life", the lived life which "can never be separated from its form, a life in which it is never possible to isolate something such as naked life" (Agamben, 1996, pp. 2-3); cf. (Oliver, 2008) and (Wadiwel, 2015).

Understood in these terms, the world being built around the Xisqueta would appear to mark the transition to a properly bio-economic formation. In this world, the naming of the sheep has a very different role than it did for Dolly, because, rather than serving to domesticate the synthetic bio-reactor, the act of naming enacts a node, which binds the local and global, as well as the human and the non-human, into a singular and transformative agro-ecological singularity. As such, the act of naming might be regarded as registering something like Haraway's "encounter", a source of value that exceeds utility and fungibility. At the same time, however, such framing overlooks the suspension marked out by the elliptical phrase "i li posis un nom ...". This conjunction of action and its suspension is better understood as registering a Deleuzian intensive field (Deleuze, 2004, pp. 316-7); see also (Mader, 2014). This is a field of possibilities which comprises, but does not coincide with either sheep, shepherds or place. Instead, each of these elements is the product of distinct historical 
processes, whose confluence and knotting into a singularity transforms what is possible. Thus, when Haraway (2008) claims that Deleuzian configurations of human and non-human animal assemblages do not deal with "actual" animals (p. 29), the charge is indisputable. What the criticism misses, however, is that, once the field takes on actual form and extension, the emerging figures are what has been given since the Biblical naming of the animal. The animal, just like the human, is a discursive construct, and, as such, the focus on the animal or even animals in their plurality could be regarded as a form fetishization; see also (Shukin, 2009). This said, rather than focusing on identities and their overcoming, one could focus instead on process as what matters most. Thus, one might acknowledge that, once actualised as the encounter of human and non-human animals, the disruptive power of the event of encounter is returned to the calculations of use and exchange value that exercise Haraway and Deleuze alike. This return does not mean, however, that nothing is then changed because the value attached to the commodities exchanged will have shifted, this being the effect or trace of doubt and uncertainty that the ritualization of consumption, which Rurbans seeks to reinscribe into the economy built around the Xisqueta, can ever repay the gift around which the relationship between human and non-human animals revolves; cf. (Steinmann, 2009) and (Evans \& Miele, 2012). The more general significance of this situation is that, as Grossberg, Hardin and Palm (2014) observe in their analysis of valuation and the contemporary, changing understanding of debt, Maussian theory of the gift can be understood as installing "obligation" as a fundamental mode of existence. They write:

[O]bligation is the necessarily positive force that defines the affective space of the social bond: the primordial stickiness that holds people together in relations of mutuality before any commonality, but out of which commonalities and collectivities can be formed (318).

From this point of view, use and exchange value are historical constructs that draw upon and reconfigure a prior, generative mode of existence. Extending the claim beyond Grossberg, 
Hardin and Palm's delimitation of this prior form of existence as pertaining to "people", this understanding of valuation suggests that the bio-economy could be said to exist on the threshold separating "actual" organisms from the proliferative powers of life in its most amorphous "molecular" form. Here, the term "molecular" is not employed in the sense intended by the opening distinctions between animal lives on the farm and configurations of life emerging from the experimental laboratory, both dealing with thoroughly ordered and codified "molar" forms, but as a way of capturing the primordial state out of which "actual" forms are forged (Deleuze \& Guattari, 1988). ${ }^{11}$ At the same time, the world built around the Xisqueta also suggests is that what matters is not so much what these diverse forms of existence are, but how these forms are put into motion and what are the effects of such mobilisation (Deleuze, 1992); see also (Buchanan, 2008) and (Buller, 2012).

\section{Conclusion}

In sum, the present discussion has sought to explore the limits of the understanding that the contemporary convergence of economy and species existence marks the emergence of a novel and distinctive formation, the "bio-economy". It has done so by focusing on three enterprises in which sheep act as the fulcrum of social and economic renewal, each enterprise operating as an abstract and idealising figure, intended to aid the understanding of different aspects of the convergence. As Cronon (2009) has observed, 'sheep are good to think with' (ix).

Birch and Tyfield (2013) have argued that much of the literature on the bio-economy fetishizes the objects that supposedly distinguish this from other forms of economic exchange; see also (Shukin, 2009). The enterprises that have developed around the Herdwick breed of sheep, native to the Lake District, and around the Sambucana, in the Maritime Alps, 
illustrate the argument. Specifically, the activities of the Consorzio l'Escaroun, a consortium dedicated to the economic valorization of the Sambucana, illustrates how the notions of place and related forms of liveliness that sustain both enterprises are not given, but are instead the fruit of social and cultural construction. In turn, Herdy, a commercial design company named after the Herdwick sheep, illustrates the power of commoditisation. Though involved in the local strategy to revitalise sheep breeding in the Lake District by securing Protected Denomination of Origin for the Herdwick, Herdy has been able to avoid the difficulties surrounding one of its principal achievements because the brand is increasingly disconnected from the Herdwick and the places in which it grazes, other than as in the same iconic manner that Dolly, the first cloned, trans-genic mammal ever produced, stands for the promises issuing from speculative markets in bio-synthetic futures. Simply put, Herdy thrives to the extent that it is disconnected from all that is lively and belongs to place. As Birch and Tyfield might put it, any argument to the effect that these different enterprises illustrate all that is distinctive about the bio-economy would mistake that which is constructed and secondary as given and the primary source of value.

Yet, for all the incisiveness of their critique, Birch and Tyfield would also seem to underestimate the importance of bodies and affect. They mobilise an "autonomist" understanding of the relationship between contemporary modes of production and consumption, in which the two converge upon the subject's corporeal existence, but they overlook how bodies mediate the convergence. As Morini and Fumagalli (2010) put it in their analysis of the creation of value within the bio-economy, not only does such creation entail the mobilisation of cognitive resources such that it is necessarily a collective enterprise, but the nature of the affective relations thus transformed results in a co-constitutive and reciprocal relationship between bodies, networks of consumption and the production of value 
such that no single component can be separated from any other. From an autonomist perspective, the challenge then is how to redirect the flows of capital within this complex formation. Very usefully, Morini and Fumagalli refer to the growing importance within the bio-economic context of all that is different, exemplifying this by pointing to the increasing valorisation of "indigenous or local systems" (p. 238). As if to respond to the challenge thus posed, Rurbans, the enterprise built around sheep of the Catalan Pyrenees, illustrates how the strategies developed around the Sambucana and the Herdwick might be redirected to counterhegemonic ends, by enacting a bio-politics in which all actors are called upon to move outside themselves, connecting with others, human and non-human. Morini and Fumagalli draw out the fuller and more general implications of such an economy when they go on to inquire about the identity and capacities of the bodies mobilised under "biocapitalism". They write:

\footnotetext{
[W]ithin biocapitalism, precisely because of its being reticular/non linear, a static idea of identity - perceived as permanent essence - is simply unthinkable. On the very contrary, identity ceases to be a stable datum to gradually become a process of identification that is incessantly constructed and restructured through different faces, roles and circumstances, both at the individual and the collective level. The identity of the multiple I - as we think of it - is configured as a field rather than as an essence. It is not a sort of metaphysical reality, but rather a dynamic system defined by potentialities and limits (which is to say, by relations) that can be theoretically recognized and practically transformed (p. 239).
}

In other words, the relational and dynamic nature of the bio-capitalist assemblage requires any transformative forces to focus not on identities, be they those of the consuming subject or the objects consumed, but on the processes at work, and to mobilise the latter to the advantage of these forces. While Morini and Fumagalli's notion of a "general intellect" driving the process of bio-economic transformation may speak to an anthropocentric understanding of the actors involved in the process, which Porcher (2017) seeks to overcome, the Deleuzian overtones of the language which Morini and Fumagalli employ to advance their argument is no coincidence; see (Negri, 2008); also (Shukin, 2009), (Chrulew, 2012) 
and (Nelson \& Braun, 2017). This language is a direct consequence of their search for the immanent understanding of the multitude and its insurgent, transformative powers, which can only be ignored as considerable cost because it is the defining feature of autonomism. Forgetfulness of fields of intensity, such as those evinced in the moment of encounter and the resulting movement of differentiation, can only freeze the generative capacities of life itself into their most unproductive and unpromising forms, including the contemporary opposition of material, species existence and the bio-capitalist discursive order; see (Deleuze \& Guattari, 1984) and (1988). In other words, if the "capitalocentrism of so much writing on biocapitalism" (Helmreich, 2008, p. 474) is to be answered effectively, this endeavour calls for greater attention to the dynamics of life itself and beyond the certainties invested in any “actual" forms; see also (Povinelli, 2017) and (Stengers, 2017).

Viewed from this perspective, Rurbans could then be said to exemplify the kind of alternative bio-politics that both Campbell, Le Heron, Lewis, and Carolan (2016) and Despret and Meuret (2016) envision, namely the actualisation of alternative visions of what the world might be, by forging connections between singularities and beyond the confines of any fixed identity. As Herdy's investment in the fate of the Herdwick intimates, the differences enacted may very well be captured by the commodity form and related exchange value, just as Shukin (2009) proposes, but, in the process, they also change the world and its manifold possibilities. As Law and Mol (2008) write of encounters with Herdwick sheep,

\footnotetext{
We might say that an actor is a moment of indeterminacy that generates events and situations. It does this together with other actors that enact it and that it, in its turn, enacts. And it does so for better, or for worse, or both. Or, then again, we might say that an actor is the site where we situate what surprised us post hoc when we tell stories about events and situations (p. 74).
}

The narratives we enact matter, in the verbal sense of this term, and this is perhaps another way of encapsulating the liveliness of the bio-economy, beyond commodity fetishism and the 
oppositions of discursive and material foundations that sustain the fetish (Bennett, 2001, pp. 111-130). 


\section{Notes}

${ }^{1}$ Practices of valuation comes in diverse guises. As Dussauge, Helgesson, Lee and Woolgar (2015) observe, such diversity currently is the object of critical inquiry, particularly in relation to the many disruptive effects of the contemporary convergence of economic exchange and species existence.

${ }^{2}$ Sheep have long been iconic, and so have their breeds. On the history of sheep, see (Ryder, 2007) and (Armstrong, 2016). For an equally historical perspective on the iconic functions of breeds, including ovine breeds, see instead (Woods, 2017).

${ }^{3}$ For a discussion of the conceptual foundations of the approach taken, see (Berry \& Palladino, in press), where arguments over the nature of another breed of sheep are the site of reflection on relationships between different modes of conceiving relations between time and value.

${ }^{4}$ One of this paper's reviewers has asked whether the understanding of the world built around the Xisqueta might not be extended to the Herdwick and whether this might not invalidate the argument that the paper seeks to advance. Consistent with a Weberian understanding of ideal types, the aim here is not to identify the essential characteristics of three different bio-economic formations, but to mobilise differences between the three enterprises at issue to better understand the dynamics and composition of forces shaping a more general relationship, here between affect and the production of value within bio-economic formations.

${ }^{5}$ Helmreich employs the anthropological distinction between "formalist" and "substantivist" accounts of economic life (p. 471). The distinction between discursive and materialist approaches is consistent with Helmreich's argument and does not discount the possibility that these approaches might be equally historicist. In other words, the approach proposed here seeks to be more symmetric with respect to two different modes of thought about the relationship between organic materials and economic exchange.

${ }^{6}$ While Shukin adopts Derridean and Deleuzian modes of inquiry, Shukin also argues that the ontologies sustaining these modes are complicit with the destructive power of capitalist forms of exchange. Shukin's implicit naturalism about organisms is examined in a more detailed investigation of the enterprise around the Sambucana.

${ }^{7}$ For all the antagonism, Haraway's (2008) objections to Deleuzian perspectives on the encounter between human and non-human animals are best characterized as equivocal; see (pp. 27-30). Similarly, in a comprehensive review of configurations of non-human animals within continental philosophy, Oliver (2008) notes the distinctiveness of Deleuzian constructions of relations between human and non-human animals but is so ambivalent about their merits as to exclude them from any sustained analysis (pp. 307-8, n. 9).

${ }^{8}$ The enterprise around the Sambucana is the object of an ongoing, more detailed investigation. There is little evidence that the contemporary investment in the phylogenetic identity of the Sambucana is part of a longer local history comparable to that of breed societies in the United Kingdom and the British Empire (Ritvo, 1995) and (Woods, 2017); cf. (Sanna, 2011).

${ }^{9}$ Agamben argues that Deleuze's (2001) mobilization of the ellipsis to characterize the singularity of a lived life offers a wholly different way of understanding human existence. Focusing on Deleuze's formative reading of Spinoza, as well as their shared interest in those situations where existence is suspended between life and death, Agamben proposes that the hesitation conveyed by ellipsis bears witness Spinoza's understanding of life as immanent cause. Cooper (2009) disputes Agamben's reading of Deleuze and Spinoza. On the related notion of linguistic vitalism, see (Chiesa \& Ruda, 2011). 
${ }^{10}$ As one of the paper's reviewers has observed, Yi-Fu Tuan (2004) argues that naming and affection are never far removed from dominance. The point here, however, is not to dispute the importance of power, but to draw attention to fissures within its fabric.

${ }^{11}$ The notion of a form of existence that is prior to the separation of subjects and objects, as well as that between human and non-human animals, is discussed at greater length in a paper co-authored with Annalisa Colombino, particularly in relation Deleuzian and Nancean (2000) understanding of being as singular-plural. 


\section{References}

Accesstoland, n.d.. Our Network. [Online] Available at: http://www.accesstoland.eu/-Our-network- [Accessed 8 July 2016].

ACTYVA, 2013. BBBFarming: Somos Granjeros y Urbanistas en Transición. [Online] Available at: http://www.bbbfarming.net/somos [Accessed 6 July 2016].

Agamben, G., 1996. Means Without End: Notes on Politics. Minneapolis: University of Minnesota Press.

Agamben, G., 1999. Absolute immanence. In: Potentialities: Collected Essays in Philosophy. Stanford: Stanford University Press, pp. 220-239.

Ahumada, L. d., 2013. A Cel Ras: Converses amb Joves Pastors. Lleida: Pagès Editors.

Aime, M., Allovio, S. \& Viazzo, P. P., 2001. Sapersi Muovere: Pastori Transumanti di Roaschia. Roma: Meltemi.

Armstrong, P., 2016. Sheep. London: Reaktion.

Asdal, K., Druglitrø, T. \& Hinchliffe, S., 2017. The 'more than human' condition: Sentient creatures and versions of biopolitics. In: K. Asdal, T. Druglitrø \& S. Hinchliffe, eds. Humans, Animals and Biopolitics: The More-Than-Human Condition. New York: Routledge, pp. 1-29.

Associació Rurbans, n.d.. [Online] Available at: https://projectegripia.wordpress.com/about/ [Accessed 13 March 2017].

Audisio, A. \& Cordero, M. eds., 1996. La Montagna dell'Esodo: Racconti Fotografici di Clemens Kalischer, 1962-63. Torino: Museo Nazionale della Montagna.

Barua, M., 2016. Lively commodities and encounter value. Environment and Planning D: Society and Space, 34(4), p. 725-744.

Beaulieu, A., 2011. The status of animality in Deleuze's thought. Journal for Critical Animal Studies, 9(1/2), pp. 69-88.

Belting, H., 1994. Likeness and Presence: A History of the Image before the Era of Art. Chicago: University of Chicago Press.

Bennett, J., 2001. The Enchantment of Modern Life: Attachments, Crossings, and Ethics. Princeton: Princeton University Press.

Berry, D. \& Palladino, P., in press. Life, time and the organism: Temporal registers in the construction of life forms. Journal of the History of Biology.

Biffi, O., 2014. Sostenibilità e partecipazione in due aree rurali marginali: Una comparazione di progetti di sviluppo locale. EtnoAntropologia, 2(2), pp. 47-68.

Birch, K. \& Tyfield, D., 2013. Theorizing the bioeconomy: Biovalue, biocapital, bioeconomics or . . what?. Science, Technology, \& Human Values, 38(3), pp. 299-327. 
BITC, 2010. The Herdy Company: Responsible Small Business of the Year 2010. [Online] Available at: http://www.bitc.org.uk/our-resources/case-studies/herdy-company-responsible-small-business-year-2010 [Accessed 8 July 2016].

Brignone, A. \& Martini, S., 2012. La razza ovina Sambucana: Rusticità e adattamento all'ambiente. In: G. Lebaudy, P. Fabre, S. Martini \& M. E. Rosso, eds. La Routo: Sulle Vie della Transumanza tra le Alpi e il Mare. Cuneo: Nerosubianco, pp. 157-163.

Brown, G., 2009. Herdwicks: Herdwick Sheep and the English Lake District. Kirkby Stephen: Hayloft.

Buchanan, B., 2008. Onto-Ethologies: The Animal Environments of Uexküll, Heidegger, Merleau-Ponty, and Deleuze. Binghamton: State University of New York Press.

Buller, H., 2004. Where the wild things are: The evolving iconography of rural fauna. Journal of Rural Studies, 20(2), pp. 131-141.

Buller, H., 2012. One slash of light, then gone: Animals as movement. Etudes Rurales, Volume 189, pp. 139154.

Buller, H., 2013. Individuation, the mass and farm animals. Theory, Culture Society, 30(7/8), p. 155-175.

Campbell, H., Le Heron, R., Lewis, N. \& Carolan, M., 2016. Conclusion: Biological economies as an academic and political project. In: R. Le Heron, H. Campbell, N. Lewis \& M. Carolan, eds. Biological Economies: Experimentation and the Politics of Agri-Food Frontiers. Abingdon: Routledge, pp. 256-70.

Chiesa, L. \& Ruda, F., 2011. The event of language as form of life: Agamben's linguistic vitalism. Angelaki: Journal of the Theoretical Humanities, 16(3), pp. 163-180.

Chrulew, M., 2012. Animals in biopolitical theory: Between Agamben and Negri. New Formations, 76(Autumn), pp. 53-67.

Chrulew, M. \& Wadiwel, D. J., 2016. Editor's Introduction: Foucault and Animals. In: M. Chrulew \& D. J. Wadiwel, eds. Foucault and Animals. Leiden: Bill, pp. 1-15.

Colombino, A., 2018. Becoming Eataly: The magic of the mall and the magic of the brand. In: U. Ermann \& K. Hermanik, eds. Branding the Nation, the Place, the Product. London: Routledge, pp. 67-90.

Colombino, A. \& Giaccaria, P., 2015. Breed contra beef: The making of Piedmontese cattle . In: J. Emel \& H. Neo, eds. Political Ecologies of Meat. New York: Routledge, pp. 161-177.

Cooper, M., 2008. Life as Surplus: Biotechnology and Capitalism in the Neoliberal Era. Seattle: University of Washington Press.

Cooper, M., 2009. The silent scream: Agamben, Deleuze and the politics of the unborn. In: R. Braidotti, C. Colebrook \& P. Hanafin, eds. Deleuze and Law: Forensic Futures. London: Palgrave Macmillan, pp. 142-162.

Craig, G. \& Parkins, W., 2006. Slow Living. Oxford: Berg.

Cronon, W., 1992. Nature's Metropolis: Chicago and the Great West. New York: W. W. Norton.

Cronon, W., 2009. Foreword. In: Dreaming of Sheep in Navajo Country. Seattle: University of Washington Press, pp. ix-xiii.

Deleuze, G., 1992. Expressionism in Philosophy: Spinoza. New York: Zone Books. 
Deleuze, G., 2001. Immanence: A life ... [1995]. In: Pure Immanence: Essays on A Life. New York: Zone Books, pp. 25-33.

Deleuze, G., 2004. Difference and Repetition. London: Continuum.

Deleuze, G. \& Guattari, F., 1984. Anti-Oedipus: Capitalism and Schizophrenia. London: Athlone.

Deleuze, G. \& Guattari, F., 1988. A Thousand Plateaus: Capitalism and Schizophrenia. London: Continuum.

Derrida, J., 2008. The Animal That Therefore I Am. New York: Fordham University Press.

Despret, V. \& Meuret, M., 2016. Composer avec le Moutons: Lorsque des Brebis Apprennent à leurs Bergers à leur Apprendre.. Avignon: Cardère Éditeur.

Dunham, J., Grant, H., Iain \& Watson, S., 2014. Idealism: The History of a Philosophy. New York: Routledge.

Dussauge, I., Helgesson, C.-F., Lee, F. \& Woolgar, S., 2015. On the omnipresence, diversity, and elusiveness of values in the life sciences and medicine. In: I. Dussauge, C. Helgesson \& F. Lee, eds. Value Practices in the Life Sciences and Medicine. New York: Oxford University Press, pp. 1-29.

Echegaray, E. P., 2012. Señores del Paisaje: Ganadería y Recursos Naturales en Aragón, Siglos XIII-XVII. Valencia: Universidad de Valencia.

Emel, J. \& Neo, H., 2015. Introduction. In: J. Emel \& H. Neo, eds. Political Ecologies of Meat. New York: Routledge, pp. 1-17.

European Commission, 2014. Bioeconomy. [Online] Available at: https://ec.europa.eu/programmes/horizon2020/en/h2020-section/bioeconomy [Accessed 2018 January 25].

Evans, A. B. \& Miele, M., 2012. Between food and flesh: How animals are made to matter (or not to matter) within food consumption practices. Environment and Planning D: Society and Space, 30(2), pp. 298-314.

Evans, N. \& Yarwood, R., 2000. The politicization of livestock: Rare breeds and countryside conservation. Sociologia Ruralis, 40(2), pp. 228-248.

Fontana, I. R., 2004. La Transhumància Andorrana al llarg del Segle XX. Barcelona: Alta Fulla.

Foucault, M., 1977. Nietzsche, genealogy, history. In: D. Bouchard, ed. Language, Counter-Memory, Practice: Selected Essays and Interviews by Michel Foucault. Ithaca: Cornell University Press, pp. 139-164.

Foucault, M., 1980. The confession of the flesh . In: C. Gordon, ed. Power/Knowledge: Selected Interviews and Other Writings, 1972-1977. New York: Pantheon, p. 194-228.

Foucault, M., 1991. The History of Sexuality: An Introduction. Harmondsworth: Penguin.

Franklin, S., 2007. Dolly Mixtures: The Remaking of Genealogy. Durham: Duke University Press.

Goodman, J. \& Salleh, A., 2013. The 'green economy': Class hegemony and counter-hegemony.

Globalizations, 10(3), p. 411-424.

Goodman, M. K., 2016. Food geographies I: Relational foodscapes and the busy-ness of being more-than-food. Progress in Human Geography, 40(2), p. 257-266. 
Graham, B., Ashworth, G. J. \& Tunbridge, J., 2000. A Geography of Heritage: Power, Culture \& Economy. London: Arnold.

Gramsci, A., 2007. Prison Notebooks. New York: Columbia University Prees.

Grasseni, C., 2013. Beyond Alternative Food Networks: Italy's Solidarity Purchase Groups. London: Bloomsbury.

Grossberg, L., Hardin, C. \& Palm, M., 2014. Contributions to a conjunctural theory of valuation. Rethinking Marxism, 26(3), p. 306-335.

Haraway, D. J., 2008. When Species Meet. Minneapolis: University of Minnesota Press.

Helmreich, S., 2008. Species of biocapital. Science as Culture, 17(4), pp. 463-478.

Hobsbawm, E., 1983. Inventing traditions. In: E. Hobsbawm \& T. Ranger, eds. The Invention of Tradition. Cambridge: Cambridge University Press, pp. 1-14.

Holloway, L., 2015. Biopower and the ecology of genes: Seeing livestock as meat via genetics . In: J. Emel \& H. Neo, eds. Political Ecologies of Meat. New York: Routledge, pp. 178-194.

IPO, 2015. Intellectual Property: Herdy. [Online] Available at: https://www.gov.uk/government/casestudies/intellectual-property-herdy [Accessed 8 July 2016].

Kanerva, M., 2013. Meat Consumption in Europe: Issues, Trends and Debates, Bremen: s.n.

Lang, T., 2010. From ‘value-for-money' to ‘values-for-money'? Ethical food and policy in Europe. Environment and Planning A: Economy and Space, 42(8), pp. 1814-1832.

Law, J. \& Mol, A., 2008. The actor-enacted: Cumbrian sheep in 2001. In: C. Knappett \& L. Malafouris, eds. Material Agency: Towards a Non-Anthropocentric Approach. Dusseldorf: Springer, pp. 57-78.

Lebaudy, G., 2011. De la Demontine a la Sambucana. Ethnozootechnie, Volume 91, pp. 73-85.

Legg, S., 2011. Assemblage/apparatus: Using Deleuze and Foucault. Area, 43(2), pp. 128-133.

Lemke, T., 2011. Biopolitics: An Advanced Introduction. New York: New York University Press.

Luparia, S., 2000. The Sambucana sheep: A project to save a valley. Animal Genetic Resources Information, Volume 27, pp. 27-33.

Mármol, C. \& Vaccaro, I., 2015. Changing ruralities: Between abadonment and redefinition in the Catalan Pyrenees. Anthropological Forum, 25(1), pp. 21-41.

Mader, M. B., 2014. Whence intensity? Deleuze and the revival of a concept . In: A. Beaulieu, E. Kazarian \& J. Sushytska, eds. Deleuze and Metaphysics. Lanham: Lexington Books, pp. 225-247.

Mansfield, L., 2008. The Cumbria Hill Sheep Initiative: A solution to the decline in uplant farming community in England?. In: G. M. Robinson, ed. Sustainable Rural Systems: Sustainable Agriculture and Rural Communities. Aldershot: Routledge, pp. 161-183.

Marsden, T. \& Murdoch, J., 2006. Between the local and the global: Confronting complexity in the contemporary agri-food sector. In: T. Marsden \& J. Murdoch, eds. Between the Local and the Global: Confronting Complexity in the Contemporary Agri-Food Sector. Amsterdam: JAI Press, pp. 1-8. 
Monllor, N. R., 2013a. Introducció. In: A Cel Ras: Converses amb Joves Pastors. Lleida: Pagès Editors, pp. 1520.

Monllor, N. R., 2013b. La nova pagesia: Vers un nou model agrosocial. Quaderns Agraris, December, Volume 35, pp. 7-24.

Morini, C. \& Fumagalli, A., 2010. Life put to work: Towards a life theory of value. Ephemera, 10(3/4), pp. 234252.

Nancy, J.-L., 2000. Being Singular Plural. Stanford: Stanford University Press.

Negri, A., 2008. The labor of the multitude and the fabric of biopolitics. Mediations, 23(2), pp. 8-25.

Nelson, S. \& Braun, B., 2017. Autonomia in the anthropocene: New challenges to radical politics. South Atlantic Quarterly, 116(2), pp. 223-235.

Oliver, K., 2008. Animal Lessons: How They Teach Us to Be Human. New York: Columbia University Press.

Phillips, C. R. \& Phillips, W. D., 1997. Spain's Golden Fleece: Wool Production and the Wool Trade from the Middle Ages to the Nineteenth Century. Baltimore: John Hopkins University Press.

Pike, A., 2015. Origination: The Geographies of Brands and Branding. Malden: Wiley.

Ploeg, J. D. v. d., 2008. The New Peasantries: Struggles for Autonomy and Sustainability in an Era of Empire and Globalization. Abingdon: Earthscan.

Porcher, J., 2017. The Ethics of Animal Labor: A Collaborative Utopia. Cham: Palgrave Macmillan.

Povinelli, E. A., 2017. The ends of humans: Anthropocene, autonomism, antagonism, and the illusions of our epoch. South Atlantic Quarterly, 116(2), pp. 293-310.

Rabinow, P., 1996. Artificiality and enlightenment. In: Essays in the Anthropology of Reason. Princeton: Princeton University Press, pp. 91-111.

Rajan, K., 2006. Biocapital: The Constitution of Postgenomic Life. Durham: Duke University Press.

Rayner, J., 2016. Cumbrian sheep, Veronese pasta: The protection of food culture can go too far. [Online] Available at: https://www.theguardian.com/lifeandstyle/2016/mar/17/jay-rayner-food-culture-protection-too-farcumbria-sheep-verona-pasta [Accessed 5 July 2016].

Ritvo, H., 1995. Possessing mother nature: Genetic capital in eighteenth-century Britain. In: J. Brewer \& S. Staves, eds. Early Modern Conceptions of Property. Abingdon: Routledge, pp. 413-426.

Ritvo, H., 2009. The Dawn of Green: Manchester, Thirlmere, and Modern Environmentalism. Chicago: University of Chicago Press.

Rose, N., 2007. The Politics of Life Itself: Biomedicine, Power, and Subjectivity in the Twenty-First Century. Princeton: Princeton University Press .

Ryder, M. L., 2007. Sheep and Man. London: Duckworth.

Sanna, P., 2011. Il 'grande affare' delle lane e il dibattito settecentesco sull' 'ingentilimento' della pecora sarda. In: A. Mattone \& P. F. Simbula, eds. La Pastorizia Mediterranea: Storia e Diritto (Secoli XI-XX). Roma: Carocci, pp. 705-732. 
Shukin, N., 2009. Animal Capital: Rendering Life in Biopolitical Times. Minneapolis: University of Minnesota Press.

Steinmann, M., 2009. Introduction. In: M. Steinmann, P. Sýkora \& U. Wiesing, eds. Altruism Reconsidered: Exploring New Approaches to Property in Human Tissue. New York: Routledge, pp. 1-10.

Stengers, I., 2017. Autonomy and the intrusion of Gaia. South Atlantic Quarterly, 116(2), pp. 381-400.

Tuan, Y.-F., 2004. Dominance and Affection: The Making of Pets. New Haven: Yale University Press.

Twine, R., 2010. Animals as Biotechnology: Ethics, Sustainability and Critical Animal Studies. London: Earthscan.

Wadiwel, D., 2015. The War Against Animals. Leiden: Brill.

Wadiwel, D. J., 2016. Like one who is bringing his own hide to market. Angelaki: Journal of the Theoretical Humanities, 21(2), pp. 65-82.

Woods, R. J. H., 2017. The Herds Shot Round the World Native Breeds and the British Empire, 1800-1900. Chapel Hill: University of North Carolina Press. 